\title{
Epidemiological studies on Listeriosis in sheep
}

\author{
E. E. Younis ${ }^{1}$, A. A El-Sawalhy ${ }^{2}$, Soumaya E. A. ${ }^{3}$, M. A. A. El-Beskawy ${ }^{4}$ \\ ${ }^{I}$ Department of Internal Medicine and Infectious Disease, Faculty of Veterinary Medicine, \\ Mansoura University, Egypt, ${ }^{2}$ African Union/Interafrican Bureau for Animal Resources (AU/IBAR), \\ Nairobi, Kenya, ${ }^{3}$ Animal Health Research Institute, Dokki, Giza, Egypt and ${ }^{4}$ Veterinary Teaching \\ Hospital Faculty of Veterinary Medicine, Mansoura University, Egypt.
}

\begin{abstract}
This study was carried out in El-Dakahilia governorate on six flocks at different areas 2448 sheep located with varied ages and with history of nervous manifestation. The Prevalence of nervous manifestations was $4.9 \%(105 / 2448)$. The case fatality rate and mortality rate were 77.14 $\%$ and $3.3 \%$ respectively. The percent of Listeria monocytogenes was $26.66 \%(8 / 30)$. Examination of CSF of diseased and control healthy sheep revealed significance elevation of total cell count, total protein and creatinine cytokinase of diseased than control sheep.
\end{abstract}

Listeria monocytogenes is a Gram positive non sporulating rod which produce encephalitis, septicemia and abortion in both human and livestock, further more Listeria monocytogenes is a major human bacterial food born pathogen that annually accounts for an estimated 2500 cases of meningitis, encephalitis, sepsis, fetal death, premature births and 504 deaths in USA at an estimated loss of $\$ 200$ million (Irene et al., 2002).

Clinical Listeria monocytogenes isolates from humans and ruminants present many similarities and often belong to the same genetic lineages thus, ruminants and their environment may represent an important source of food contamination and infections for humans (Wagner et al., 2000).

The incidence of listeriosis in ruminants has markedly increased over the last few decades and feeding of poor-quality silage seems to be a key factor in disease transmission (Boerlin et al., 1996)

Among farm animals, sheep appear to be particularly susceptible to listeriosis. The organism is spread world-wide in nature (decaying herbage, soil, feces, and sewage) and occurs usually in low numbers (Fenlon, 1988).

The current methods for the isolation and identification of L. monocytogenes are laborious and time consuming. Therefore, molecular techniques are increasing being used as new alternative faster diagnostic methods with enhanced sensitivity and reproducibility. The diagnosis of listeriosis in ruminants, based on characteristic clinical signs, may be virtually confirmed by detection of an elevated white blood cell count, comprised principally of mononuclear cells, in the CSF (Woolford, 1990).

The first positive step in elimination of human listeriosis is the elimination of animal listeriosis so; this study designed to throw some lights on clinical, epidemiological and laboratory diagnostic studies on sheep listeriosis in Egypt.

\section{Materials and methods}

Sheep. Throughout one year, (November 2006 to October 2007) six sheep flocks, with history of nervous manifestations, in El- Dakhlia, Governorate were noticed for nervous signs as circling; head tilt drooping of the ear; blindness and recumbence, the flock number ranged from $100-800$ sheep varied in their ages and Localities.

Rabbits and Swiss white mice. Ten groups (N $=3$ ) Rabbits 0f 800-900 gm B.W. and Ten groups $(\mathrm{N}=5)$ Swiss white mice of 16-18 gm B.W. used for studying the Anton's test and pathogenisity test of Listeria monocytogens isolates, 8 group from each species for the 8 isolates and other 2 groups are control.

Blood samples. Blood samples with EDETA were collected from70 varied age sheep, 50 of them from clinically suspected and 20 from apparently normal contact sheep for hematological examination. While Blood samples were collected without anticoagulant for serum separation from 110 sheep, 50 of them were clinically suspected and 60 randomly collected samples from apparently normal contact sheep for biochemical examination and antibodies detection by ELISA. Serum samples were stored at $-20^{\circ} \mathrm{C}$ until used.

Cerebrospinal fluid (CSF). Cerebrospinal fluid (CSF) samples were collected from 24 sheep showing nervous signs (12 samples from 

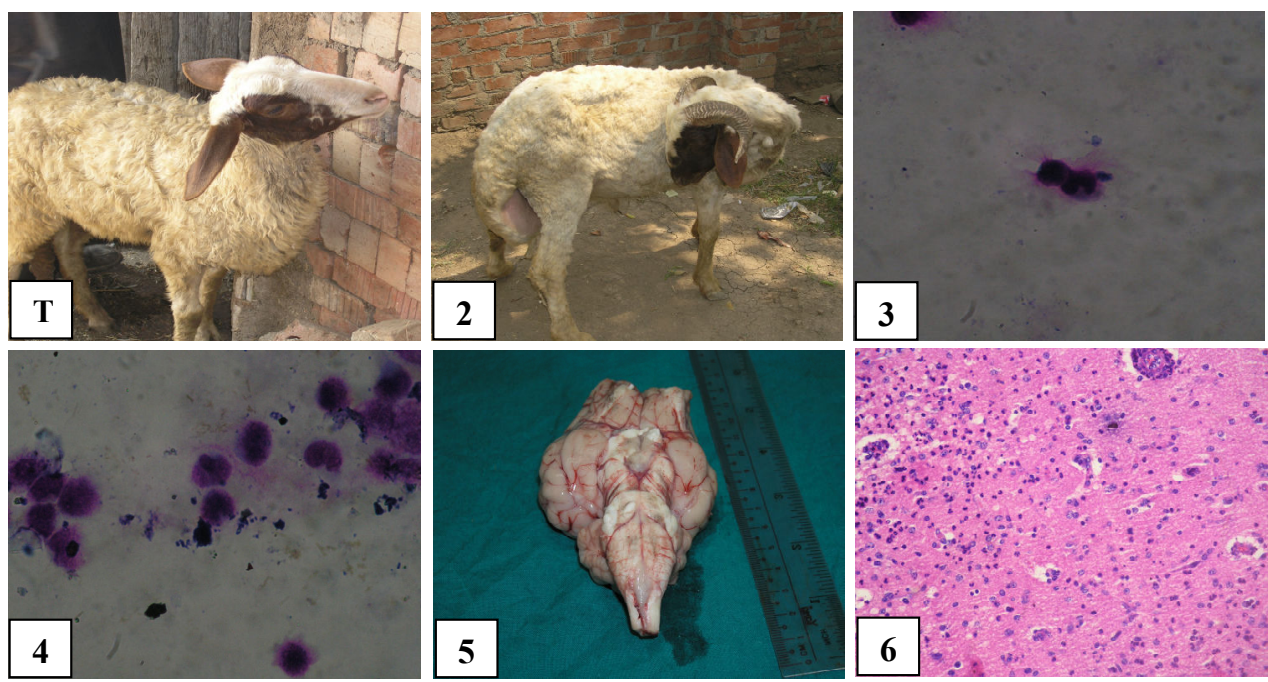

Fig. (1): Sheep showing head tilt

Fig. (2): Sheep showing twisting of the head to one side

Fig. (3): Giemsa stained film of CSF showed neutrophiles of CSF of listeriosis infected sheep

Fig. (4): Pleocytosis of Giemsa stained film of CSF of listeriosis infected sheep

Fig. (5): Congested blood vessels of brain stem of listeriosis infected sheep

Fig. (6): Brain of sheep showed microabscess represented by infiltration of gray matter with inflammatory cells mainly neutrophils.

diseased, and 12 from in contact healthy sheep) for isolation of Listeria species and for biochemical and cellular examination of CSF. The samples were put in screw sterilized caped bottle, transported to Laboratory of infectious Diseases Faculty of Veterinary Medicine Mansoura University, in cold chamber container within few hours for immediately bacteriological and cellular examination.

Postmortem examination and tissue samples. Brain, liver, spleen, and kidney tissues collected from each one of recent dead or emergency slaughtered sheep (30 samples for each organ). The selected samples divided into two parts, one was bacteriological processed for isolation of Listeria species and the other part preserved in formalin $10 \%$ for histopathological examination.

Isolation and identification of Listeria monocytogenes. It was prepared after to (Cruickshank et al., 1975).

Typing. Listeria monocytogenes was typed using molecular technique (PCR). It was applied according to (Borucki et al., 2003).

Manual erythrocytic and leukocytic count. Erythrocytes and leukocytes performed by manual method using improved neubauer hemocytometer and diluting fluids of erythrocytes and leukocytes (Feldman et al., 2000).

Determination of hemoglobin concentration (Hb). Hemoglobin concentration (Hb) (gm/dl) estimated spectrophotometrically using the cyanomethaemoglobin method according to (Drabkin, 1949).

Determination of packed cell volume (PCV). The microhaematocrite apparatus centrifuge determined it by using microhaematocrite capillary tubes according to (Drabkin, 1949).

Calculation of erythrocyte indices. Red cell indices, MCV (fl), $\mathrm{MCH}$ (pg) and MCHC (\%) were calculated from measured $\mathrm{PCV} \%, \mathrm{Hb}$ concentratrion and RBCs count according to (Feldman et al., 2000).

Differntial leukocytic count, cellular examination of CFS as well as biochemical analysis.

Biochemical analysis of CSF. They were carried out according to (Coles, 1986).

Biochemical Analysis of Blood Sera. Total serum protein, glucose, creatinine cytokinase and AST were determined spectrophotometrically using the commercial test kits according to the method described by (Henry, 1974; Young, 2001).

Indirect Enzyme-linked immunosorbent assay (ELISA). The test was applied in diagnosis of $L$. monocytogenes in diseased and apparently healthy sheep according to (Engvall and Perlmann, 1971). The obtained data in ELISA test were statistically analyzed according to (Snedecor and Cochran, 1973).

\section{Results and Discussion}

Clinical examination revealed that out of 2448 sheep located at six flocks in Dakahlia 
governorate $105(4.9 \%)$ were suffering from nervous manifestation. The varied clinical signs recorded such as dullness, depression, disorientation and head pressing against solid objects. Walking in compulsive circling, drooping of the ears and eyelids, head tilt, twisting the head to one side and hanging the food in the mouth for long period were also recorded. Losses of menace response reduced check muscle tones, recumbencey and paddling movements, detected usually before death (Fig. $1,2)$. The obtained results are in agreement with that observed by (Czuprynski, 1993; Radostits et al., 2007; Burgere, 2008). The variations in nervous signs were attributed to the site of microabcesses formation either in medulla, pons, anterior spinal cord, or in the cerebellum (Burgere, 2008). The postmortem examination revealed that necrotic foci in congested liver, highly congested kidney, cloudiness of the cerebrospinal fluid, thickened and congested meninges, congested brain and congestion of blood vessels of brain stem and cerebellum (Fig. 5) and the obtained results were in agreement with that obtained by (Seaman et al., 1990; ElSawalhy et al., 1999). These results disagreed with that observed by (Al-Dughaym et al., 2001) who observed that the postmortem picture of listeriosis of sheep was bilateral keratoconjunctivitis, lung showed multiple areas of hemorrhage, marked congestion and turbid and edematous meninges. The difference in postmortem picture may be related to the difference of the clinical form and the pathogenesis of listeriosis in sheep and most probably due to multiple causes of death. Out of 2448 examined sheep 105 diseased sheep with nervous manifestations forming morbidity rate of $4.29 \%$ as shown in Table (1), these results nearly agreement with that of (El-Sawalhy et al., 1999) who reported that the morbidity rate of affected flock of sheep suffering from listeric meningeoencephalitis was $5.81 \%$. This result similarity may be due to the same area of examination in the same governorate and under the same environmental conditions. On the other hand, disagreed with (Kumar et al., 2007) who recorded three outbreaks of encephalitic listeriosis in sheep in India with cumulative morbidity of $7.89 \%$ and (Gitter et al., 1986) who said that encephalitic listeriosis is more prevalent among ruminants, especially sheep, with an attack rate of approximately $10-12 \%$. This difference may due to the difference in mangemental system and feeding system, which act as risk factor for sheep listeriosis.

The total case fatality rate and mortality rate were $77.14 \%$ and $3.3 \%$ respectively which in agreement with that obtained by (Gitter et al., 1986) and disagreed with that obtained by (Kumar et al., 2007) who recorded that the cumulative mortality and case fatality rate of listeriosis were, $7.08 \%$ and $89.85 \%$ respectively.

The mortality and fatality rates differences may attributed to the age factor as young age is usually highly susceptible and the encephalitic form usually fatal and none responsive to treatment which supported by (Radostits et al., 2007).

With special orientation to the age, the group of sheep aging 3-6 months old showed highest nervous manifestations (Table 1). The high attack rate in lambs attributed to the age of teeth eruption, teeth loss or injury in the mouth cavity and low attack rate in adult may be due to previous exposure to the disease and development of partial immunity to listeriosis. The obtained results were in agreement with that obtained by (Wilesmith and Gitter, 1986), they recorded that the encephalitic form is the commonest and the attack rate in lambs ranged from $1.1 \%$ to $7.5 \%$ and the affected lambs were between 4 and 9 months old. Burdarov and Buvadorova, (1987) recorded an outbreak of listeric encephalitis among lambs between 10 days and 6 months of age in Bulgaria. Barlow and McGorum, (1985) suggested that listerial encephalitis in sheep was most common in winter and early spring in the age groups of sheep, which would be cutting, changing and possibly losing teeth. In India (Kumar et al., 2007) recorded low incidence in sheep below 6 months of age with cumulative morbidity of $3.75 \%$ as compared to $9.5 \%$ in sheep above 6 months of age. The variation in age susceptibility may be due to variation in environment and the nature of feeding material, which make a risk factor in encephalitic listeriosis. and this supported by (Malik et al., 2002), who reported that the encephalitic form of listeriosis results from trigeminal nerve infection consequent to abrasions of the buccal mucosa with feed or infection of teeth cavities.

The prevalence rate of ovine encephalitic listeriosis related to the season shown in (Table 2). The occurrence of listeriosis all round the year explained as Listeria monocytogenes tolerate the adverse environmental conditions and survive at temperature of $4-40^{\circ} \mathrm{C}$. The high 
percent of encephalitic listeriosis in winter season attributed to several risk factors including, climatic changes, overcrowding, feeding of stored food and fecal contamination of feed during winter. This explanation were supported by Scott, (1993), who mentioned that, encephalitic listeriosis can occur at any time of the year, but most frequently in winter season, predisposing factors in winter are likely to include housing of animals, which increase animal density and fecal contamination in the environment, feeding of stored feed and stress associated with adverse weather, in the UK. While in autumn months, which comes after summer months where as feeding on stumps of crops of wheat, barley, cotton and corn, which may be causing injurious to the oral cavity, which are predispose cause to ovine listeriosis, while in summer feeding of dry stored feed may facilitate the occurrence of listeriosis. These results are in agreement with that obtained by Scott, (1993); El-Sawalhy et al., (1999); Malik et al., (2002); Burgere, (2008).

Concerning to locality, the result revealed that Aga flocks had the highest percent of listeriosis (14\%) (Table 3). The high prevalence of listeriosis in Aga and Mansoura flocks attributed to the managemental system and hygienic measures, where they confinement indoors, feeding in closed pens and over crowded. In addition most of these flocks were yearling sheep (150 out of 250 ) and (74 out of 108) for Aga and Mansoura flocks respectively, which are common susceptible age to encephalitic listeriosis. These results coincided with that of Kumar et al., (2007) who reported that outbreaks of listeriosis can occur without feeding the silage and poor quality pastures (unhygienic) is considered the source of infection in addition the rotten vegetables or faecal contaminated pastures are posing great threat to the sheep industry. Radostits et al., (2007) recorded that predisposing factors to listeriosis which have been observed or proposed to cause lowering of the host's resistance to infection include a poor nutrition state, a sudden change in the weather, poor access to grazing pastures, stress of advanced pregnancy, over crowding and unhygienic conditions.

In the present study, the antibody titers were measured in diseased and apparently healthy and control sheep from free flocks of listeriosis using Enzyme Linked Immunosorbent Assay (ELISA). There was a significant increase in antibodies titers in diseased sheep than incontact apparently healthy ones at $\mathrm{P}<0.001$ (Table 4). These results were in agreement with Low and Donachie, (1991); Chaudhari et al., (2004).

The detection of anti Listeria monocytogenes antibodies in the apparently healthy and diseased sheep revealed significance difference between diseased and healthy sheep. Out of 50 serum samples of diseased sheep with nervous manifestations due to Listeria monocytogenes there were $15(30 \%)$ positive for listeria antigen and out of 60 serum samples of healthy sheep there were $9(15 \%)$ positive for listeriosis.

Serological tests, such as the most widely used agglutination methods and complement fixation test lack the sensitivity to detect the weak antibody response frequently seen in confirmed listerial infection Miettinin et al., (1990). Moreover, this was obvious clear from Table (4) where the use of ELISA cannot be a reliable method to be used in serodiagnosis of listeriosis. The seroconversion in apparently healthy sheep may be attributed to the different clinical forms of listeriosis in sheep and there is another source of infection, which is clinically undetected (Weber et al., 1995).

The genetic basis for serotype identification is not well defined, genetic analysis indicates that the evolution of somatic and flageller antigens have paralleled that of many other genes Call et al., (2003), therefore, serotyping by PCR primers may be designed as an alternative to the slide agglutination method of serotyping (Borucki et al., 2003).

The isolated Listeria monocytogenes isolates were typed by polymerase chain reaction, which revealed that 3 out of 8 isolates were serotype $1 / 2$ a representing $(37.5 \%), 3$ out of 8 isolates were $1 / 2 b$ in a percent of (37.5\%), and 2 isolates were untyped (25\%) (Table 5). These results coincised with that obtained by (El-Sawalhy et al., 1999) who succeeded in isolating Listeria monocytogenes types $1 / 2 \mathrm{a}$ and $4 \mathrm{~b}$ from an outbreak of listerial meningeoencephalitis of sheep using the serological identification in the same area. The obtained results were go in parallel with results of The Listeria monocytogenes serotypes $1 / 2 a$ and $1 / 2 b$ were isolated from ovine encephalitis by $(54.16 \%)$ and (20.83) (Low et al., 1993). Thus it is obvious that serotype $1 / 2 \mathrm{a}$ and $1 / 2 \mathrm{~b}$ the most common isolated serotypes from ovine meningoencephalitic listeriosis as recorded by (Miettinin et al., 1990; Low et al., 1993; El-Sawalhy et al., 1999). Moreover, in agreement with (Borucki et al., 2003) who reported that identification of 
Listeria monocytogenes by using PCR primers would further increase the ease and accessibility of this classification system.

In ruminant species cerebrospinal fluid collection and analysis provides rapid and in some situations instant information to the veterinary clinician investigating a disease problem in the living animal. CSF analysis is particularly useful with respect to confirming the presence of inflammatory lesion involving bacterial meningoencephalitis. CSF can be obtained from living animal and analysis results are available within 1 hour of submission to the laboratory, where essential as an accurate diagnosis as soon as possible was obtained in order to expedite preventive and control measures.

The chemical and cellular parameters of CSF of listerial meningoencephalitis of sheep showed in Table (6). Physical examination revealed that cloudiness of CSF with increased viscosity as compared with normal CSF of control or in contact sheep, these results are in agreement with those of (Scott, 1992) which could be attributed to the increased CSF protein concentration and pleocytosis ( Fig. 3, 4)

Cellular examination of CSF of diseased and control healthy sheep as shown in (Table 6), revealed significance $(p<0.0004)$ elevation of total cell count, increase of polymorphic cells and monomorphic cells in encephalitic listeriosis in comparison to control sheep, which in turn suggests bacterial meningitis or suppurative none septic meningitis. This results in concern with that reported by (El-Sawalhy et al., 1999); Scott, 1993 and 1995).Chemical examination of CSF revealed increase of total protein of diseased sheep $(2.7 \pm 0.46 \mathrm{~g} / \mathrm{dl})$ in comparison to in contact healthy ones $(1.84 \pm 0.27 \mathrm{~g} / \mathrm{dl})$. these results are in agreement with that reported by (Gronstol, 1979; El-Sawalhy et al., 1999; Scott, 2004), who measured total protein in CSF in diseased sheep as $(2.25 \mathrm{~g} / \mathrm{dl})$. The increased CSF proteins could be due to increased permeability of blood brain barrier or increased intrathecal globulin production or interruption of CSF flow and /or absorption.

None significant increase of total protein in some cases could be attributed to the early stages of the disease, and this supported by (Scott, 1992; Kumar et al., 2007) who recorded that the total protein in CSF in advanced stages of the disease was $11 \mathrm{mg} / \mathrm{dl}$ and $3.5 \mathrm{mg} / \mathrm{dl}$ in initial stages of meningoencephalitis listeriosis in sheep. The increase of CSF albumin in diseased sheep could be due to damage of the blood brain barrier or hemorrhage as reported by Baily and Vernau, (1997).

Creatinine cytokinase (CK) showed significant elevation $(18.4 \pm 3.05 \mathrm{IU} / \mathrm{L})$ in diseased than control $(12.8 \pm 3.96 \mathrm{IU} / \mathrm{L})$ $(p<0.0110)$ (Table 8). The increase of CK in the CSF is due to the nervous tissue damage and necrosis. These results are go hand in hand with that obtained by El-Sawalhy et al., (1999).

CSF glucose level was non-significant increased $(42.0 \pm 4.39 \mathrm{mg} / \mathrm{dl})$ (Table 6). This result similar to that obtained by Kumar et al., (2007) who detected increase of glucose level in diseased sheep $(97.83 \mathrm{mg} / \mathrm{dl})$ than healthy ones (56.16 mg/dl), While El- Sawalhy et al., (1999) showed decrease in the glucose level in diseased sheep $(31.05 \pm 1.18 \mathrm{mg} / \mathrm{dl})$ than healthy sheep $(51.76 \pm 1.75 \mathrm{mg} / \mathrm{dl})$. This reduction in glucose level may be attributed to the glycolytic activity of the infectious microorganisms or to increased use of glucose by bacteria and WBCs.

Hematological examination of blood of sheep suffering from listerial meningoencephalitis as shown in Table (7) revealed increased total leucocytic count with increased number of neutrophils in the examined blood of diseased sheep and this is in agreement with that obtained by Scott, (2004). Increased PCV and MCH in diseased sheep could be attributed to the dehydration of the animals due to off food and salivation and loss of bicarbonate in saliva. The biochemical values of blood in encephalitic Listeria monocytogenes infection observed that the level of CK, AST, glucose and total protein was non-significant increased as compared with that of control healthy sheep, this is supported by Morin (2004); Scott, (2004).

Histopathological examination of sheep with meningoenceplalitic listeriosis clarified typical lesions of listeriosis in sheep (Fig. 6), which described by Jubb et al., (1985), who reported that the brain show edema and small accumulation of lymphocytes and macrophages and sometimes few neutrophils around or in close proximity to blood vessels of the brain. The results were also in agreement with that obtained by (El- Sawalhy et al., 1999, Campero et al., 2002). Soumaya and Amer, (2002) revealed that all cases showed multiple microabscess in the brainstem between the midbrain and upper cervical spinal cord and added that microscopic findings consisted of single or multiple microabscess with necrotic and liquifactive changes with infiltration by 
Table (1): Morbidity, mortality and case fatality rate of nervous manifestations in sheep in relation to the age after isolation of Listeria monocytogenes.

\begin{tabular}{lcccccc}
\hline $\begin{array}{l}\text { Age } \\
\text { groups }\end{array}$ & $\begin{array}{c}\text { Total No. } \\
\text { examined }\end{array}$ & $\begin{array}{c}\text { Diseased } \\
\text { No. }\end{array}$ & $\begin{array}{c}\text { Morbidity } \\
\text { rate (\%) }\end{array}$ & $\begin{array}{c}\text { Dead } \\
\text { No. }\end{array}$ & $\begin{array}{c}\text { Mortality } \\
\text { rate (\%) }\end{array}$ & $\begin{array}{c}\text { Case fatality } \\
\text { rate (\%) }\end{array}$ \\
\hline Group I & 553 & 41 & 7.4 & 34 & 6.15 & 82.92 \\
Group II & 1202 & 51 & 4.24 & 39 & 3.24 & 76.47 \\
Group III & 693 & 13 & 1.88 & 8 & 1.15 & 61.53 \\
Total & $\mathbf{2 4 4 8}$ & $\mathbf{1 0 5}$ & $\mathbf{4 . 2 9}$ & $\mathbf{8 1}$ & $\mathbf{3 . 3 1}$ & $\mathbf{7 7 . 1 4}$ \\
\hline
\end{tabular}

Group I: Sheep aging 3 months to 6 months old

Group II: Sheep aging 6 months to 12 months

Group III: Sheep aging over 12 months

Table (2): Morbidity, mortality and case fatality rate of nervous manifestations in sheep in relation to season after isolation of Listeria monocytogenes.

\begin{tabular}{lcccccc}
\hline Season & $\begin{array}{c}\text { Total No. } \\
\text { examined }\end{array}$ & $\begin{array}{c}\text { Diseased } \\
\text { No. }\end{array}$ & $\begin{array}{c}\text { Morbidity } \\
\text { rate (\%) }\end{array}$ & $\begin{array}{c}\text { Dead } \\
\text { No. }\end{array}$ & $\begin{array}{c}\text { Mortality } \\
\text { rate (\%) }\end{array}$ & $\begin{array}{c}\text { Case fatality } \\
\text { rate (\%) }\end{array}$ \\
\hline Winter & 508 & 36 & 7.08 & 30 & 5.9 & 83.33 \\
Spring & 1392 & 46 & 3.3 & 36 & 2.6 & 78.26 \\
Summer & 381 & 13 & 3.41 & 8 & 2.1 & 61.53 \\
Autumn & 167 & 10 & 5.98 & 7 & 4.19 & 70 \\
Total & 2448 & 105 & 4.29 & 81 & 3.31 & 77.14 \\
\hline
\end{tabular}

Table (3): Morbidity, mortality and case fatality rate of nervous manifestations in sheep in relation to locality after isolation of Listeria monocytogenes.

\begin{tabular}{lcccccc}
\hline Locality & $\begin{array}{c}\text { Total No. } \\
\text { examined }\end{array}$ & $\begin{array}{c}\text { Diseased } \\
\text { No. }\end{array}$ & $\begin{array}{c}\text { Morbidity } \\
\text { rate \% }\end{array}$ & $\begin{array}{c}\text { Dead } \\
\text { No. }\end{array}$ & $\begin{array}{c}\text { Mortality } \\
\text { rate \% }\end{array}$ & $\begin{array}{c}\text { Case fatality } \\
\text { rate\% }\end{array}$ \\
\hline Belkas flock** & 799 & 35 & 4.38 & 30 & 3.75 & 85.7 \\
Dikernis flock* & 167 & 8 & 4.79 & 6 & 3.6 & 75 \\
Sherbeen flock ** & 524 & 6 & 1.14 & 4 & 0.76 & 66.66 \\
Mansoura flock * & 108 & 9 & 8.33 & 6 & 5.55 & 66.66 \\
Sinbellaween flock ** & 600 & 12 & 2 & 9 & 1.5 & 75 \\
Aga flock ** & 250 & 35 & 14 & 26 & 10.4 & 74.43 \\
Total & 2448 & 105 & 4.29 & 81 & 3.31 & 77.14 \\
\hline
\end{tabular}

* Management system is indoors "rearing in closed system"

**Management system is free grazing system.

Table (4): Optical density means in serum of diseased, contact and healthy control sheep against Listeria monocytogenes antigen by using indirect ELISA.

\begin{tabular}{|c|c|c|c|c|c|c|}
\hline \multirow{2}{*}{ State of animals } & \multirow{2}{*}{$\begin{array}{c}\text { No. of } \\
\text { animals }\end{array}$} & \multicolumn{2}{|c|}{+ +Ve ELISA } & \multirow{2}{*}{$\begin{array}{c}\text { Mean O. P. D. } \\
\pm \text { SD }\end{array}$} & \multicolumn{2}{|c|}{-Ve ELISA } \\
\hline & & No. & $\%$ & & No. & $\%$ \\
\hline Randomly selected contact sheep & 60 & 9 & 15 & $432.6 \pm 321.21$ & 51 & 85 \\
\hline $\begin{array}{l}\text { Diseased sheep from which Listeria } \\
\text { monocytogenes isolated }\end{array}$ & 8 & 8 & 100 & $517.9 \pm 344.43$ & 0 & 0 \\
\hline $\begin{array}{l}\text { Diseased sheep without trial of } \\
\text { isolation }\end{array}$ & 50 & 15 & 30 & $445.52 \pm 272.9$ & 35 & 70 \\
\hline Control from free flocks & 10 & 0 & 0 & $89 \pm 119$ & 10 & 100 \\
\hline
\end{tabular}

neutrophils and mononuclear cells located either in grey and or white mat

From this study, we can conclude that, Listeriosis is one of the important diseases of sheep causing deaths and economic losses in area of study. Attention must be paid to young age sheep as they are more susceptible to listeriosis and separation between young and adults in grazing order is advisable. The common serotypes of Listeria monocytogenes isolated in Dakahlia Governorate were $1 / 2 \mathrm{a}$ and $1 / 2 \mathrm{~b}$. Although ELISA test cannot be a reliable method for serodiagnosis of listeriosis but can help in control strategies in handling the flocks. CSF cellular and biochemical examination may help in addition to histopathology and bacteriological examination in diagnosis of listeriosis in sheep. 
Table (5): Typing of isolated Listeria monocytogenes using PCR.

\begin{tabular}{llll}
\hline $\begin{array}{l}\text { No. of isolated listeria } \\
\text { monocytogenes. }\end{array}$ & $\begin{array}{l}\text { L. monocytogens } \\
\mathbf{1 / 2 a}\end{array}$ & $\begin{array}{l}\text { L. monocytogens } \\
\mathbf{1 / 2 b}\end{array}$ & $\begin{array}{l}\text { L. monocytogens } \\
\text { Untybable }\end{array}$ \\
\hline 8 & 3 & 3 & 2 \\
$\%$ & 37.5 & 37.5 & 25 \\
\hline
\end{tabular}

Table (6): Cellular examination and biochemistry of CSF from diseased and incontact sheep (Mean \pm SD).

\begin{tabular}{llllllllll}
\hline Group & TCC & Mono & poly & CK & AST & Glu & TP & AL & A/G \\
\hline Control & 36.00 & 26.8 & 9.2 & 12.8 & 25.4 & 36.6 & 1.84 & 0.018 & 0.01 \\
& \pm & \pm & \pm & \pm & \pm & \pm & \pm & \pm & \pm \\
& 7.08 & 4.43 & 1.92 & 3.96 & 4.98 & 4.21 & 0.27 & 0.004 & 0.00 \\
Diseased & 620.2 & 282.8 & 337.4 & 18.4 & 29.8 & 42.0 & 2.7 & 0.066 & 0.025 \\
& \pm & \pm & \pm & \pm & \pm & \pm & \pm & \pm & \pm \\
& $36.03 *$ & $38.69 *$ & $40.29 *$ & $3.05^{*}$ & $4.15 *$ & $4.39 *$ & $0.46^{*}$ & $0.018^{*}$ & 0.005 \\
\hline
\end{tabular}

TCC: Total cell count

Mono: Monomorhpic cells

Poly: polymorphic cells

$\mathrm{CK}$ : Creatinine cytokinase $(\mathrm{u} / \mathrm{L})$
AST: Aspartate aminotransferase $(\mathrm{u} / \mathrm{L})$

TP: Total proteine $(\mathrm{gm} / \mathrm{dl})$

AL: Albumin (gm/dl)

A/G: Albumine globuline ratio

Table (7): Hematological examination of blood samples of diseased and incontact sheep.

\begin{tabular}{|c|c|c|c|c|c|c|c|c|c|c|c|c|}
\hline Group & RBCs & HB & PCV & MCV & МСH & МСНС & TLC & Lymph & Neutro & Mono & Eosino & Band \\
\hline Control & \pm & \pm & \pm & \pm & \pm & \pm & \pm & \pm & \pm & & & \pm \\
\hline & 12.312 & 12.098 & 35.8 & 28.95 & 9.79 & 33.96 & 17140 & 4567.6 & 10939.8 & 483.4 & 744.8 & 539.8 \\
\hline Diseased & \pm & \pm & \pm & \pm & \pm & \pm & \pm & \pm & \pm & \pm & \pm & \pm \\
\hline & 1.687 & $1.487^{*}$ & $3.114^{*}$ & 3.79 & $1.7^{*}$ & $4.51 *$ & $1465.6^{*}$ & $1624.5 *$ & $1225.44 *$ & 374.7 & 263.19 & 375.3 \\
\hline
\end{tabular}

RBCs" Red blood cell count (million/ $\mu \mathrm{l}$ )

HB: Hemoglobin concentration (gm/ dl)

PCV: Packed cell volume \%

MCV: Mean corpuscular volume (fl)

MCHC: Mean (\%gm).

Table (8): Serum biochemistry examination of diseased and incontact sheep.

\begin{tabular}{lllllll}
\hline Group & CK & AST & Glucose & TP & albumin & A/G \\
\hline Control & $219.0 \pm 28.8$ & $78.9 \pm 17.09$ & $75.8 \pm 15.7$ & $7.094 \pm 0.27$ & $2.86 \pm 0.476$ & $0.654 \pm 0.15$ \\
Diseased & $228.0 \pm 47.6$ & $77.53 \pm 19.16$ & $81.2 \pm 12.79$ & $7.57 \pm 0.458$ & $3.03 \pm 0.262$ & $0.678 \pm 0.095$ \\
\hline
\end{tabular}

AST: Asprtateaminotransferase $(\mathrm{u} / \mathrm{L})$

AL: Albumine (gm/dl)

TP: total protein $(\mathrm{gm} / \mathrm{dl})$

CK: Creatininecytokinase $(\mathrm{u} / \mathrm{L})$

\section{References}

Al-Dughaym, A. M.; Elmula, A. F.; Mohamed, G. E.; Hegazy, A. A.; Radwan, Y. A.; Housawi, F. M. T. and Gameel, A. A. (2001): First report of an outbreak of ovine septicaemic listeriosis in Saudi Arabia. Rev. Sci. tech. Off. Int. Epiz., 20 (3), 777-783.

Baily, C. S. and Vernuan, W. (1997): Cerebrospinal fluid in Clinical biochemistry of domestic animals. $5^{\text {th }}$ edition, Academic press pp. 785- 827.

Barlow, R. M., and McGorum, B. (1985): Ovine listerial encephalitis: analysis, hypothesis and synthesis. Vet. Rec., 116:233-236.

Boerlin, P.; Bannerman, E.; Jemmi, T. and Bille, J. (1996): Subtyping Listeria monocytogenes isolates genetically related to the Swiss epidemic clone. J. Clin. Microbiol., 34:2148-2153.

Borucki, M. K.; Krug, M. J.; Muraoka, W. T. and Call, D. R. (2003): Discrimination among Listeria
TLC: Total leukocytic count $(\mathrm{Th} / \mathrm{ml})$

Lymp: lymphocytes

Neutro: neutrophilis.

Mono: monocytes MCH: (p. g)

Eosino: Eosinophil
A/G: Albumine globuline ratio monocytogenes isolates using a mixed genome DNA microarray. Vet. Microbiol., 92:351-362.

Burdarov, I. and Burdarova S. S. (1987): Seasonal dynamics and prophylaxis of the meningoencephalitis form of listeriosis in lambs. Vetrinaromeditstinki Nauki., 24(8): 23-27.

Burgere, S. P. (2008): Ovine Listeriosis. Small Rumin. Res., 76 (1-2): 12-20.

Call, D. R.; Borucki, M. K. and Besser, T. E. (2003): Mixed-genome microarrays reveal multiple serotype and lineage-specific differences among strains of Listeria monocytogenes. J. Clin. Microbiol., 41:632-639.

Campero, C. M.; Odeon, A. C.; Cipolla, A. L.; Moore, D. P.; Poso, M. A., and Odriozola, E. (2002): Demonstration of Listeria monocytogenes by immunehistochemistry in formalin-fixed brain tissues from natural cases of ovine and bovine encephalitis. J. Vet. Med. B Infect. Dis. Vet. Pub. Hlth., 49:379-383. 
Chaudhari, S. P.; Malik, S. V. S.; Chatlod, L. R. and Barbuddhe, S. B. (2004): Isolation of pathogenic Listeria monocytogenes and detection of antibodies against phosphotidylinositol.specific phospholipase $\mathrm{C}$ in buffaloes. Comp. Microb. Imm. Infec. Dis.,.27:141-148.

Coles, E. H. (1986): Cerebrospinal fluid in: Veterinary clinical pathology. Saunders Company. pp 267-278.

Cruickshank, R.; Duguid, J. P.; Marmion, B. P. and Swain, R. H. A. (1975): Medical Microbiology. $12^{\text {th }}$ Ed. Vol. 2. Churchill, Livengstone, LTD, Edinburgh, London, UK

Czuprynski, C. J. (1993): Listeria. In Gyles C. L., Thoen C. O. (eds): Pathogenesis of bacterial infections in animals, $2^{\text {nd }}$ ed Iowa State University Press, Ames, Iowa, $\mathrm{p} 70$.

Drabkin, D. L. (1949): Standerization of hemoglobin measurements in Fish medicine. Stoskopf, K.M.(ed.)(1993) $1^{\text {st }}$ ed. W.B. Sawders Co. Philadelphia. pp 114-115.

El-Sawalhy, A. A.; Fouda, T. A. and El-Sheib, A. F. (1999): An outbreak of ovine Listerial Meningeoencephalitis in Dakahlia Province. Zag. Vet. J. 27(5): 122-134.

Engvall, E. and Perlmann, P. (1971): Enzyme-linked immunosorbent assay (ELISA): quantitative assay of immunoglobulin G. Immunochem., 8: 871-874.

Feldman, B. F.; Zinkl, J. G. and Jain, V. C. (2000): Schlams veterinary hematology $5^{\text {th }}$ ed. Lippincott, Williams and Wilkins. Canada. pp 1145-1146.

Fenlon, D. R. (1988): Listeriosis. In: Silage and health. BA Stark \& JM Wilkinson (Eds.). Chalcomb Publications , Marlow, Bucks, U.K. pp.7-17.

Gitter, M.; Stebblings, R. S.; Morris, J. A.; Hannam, D. and Harris, C. (1986): Relationship between ovine listeriosis and silage feeding. Vet. Rec., 118:207-208.

Gronstol, H. (1979): Listeriosis in sheep Listeria monocytogenes and immunological state in healthy sheep. Acta. Vet. Scand., 20(2): 168-179.

Henry, R. J. (1974): Clinical chemistry, principles and techniques. $2^{\text {nd }}$ ed. Harper and Row. pp: 525 .

Irene, V. W.; David, J. L.; Karen M. H.; John B. L. and Ramos, S. (2002): A case report of sporadic ovine listerial menigoencephalitis in Iowa with an overview of livestock and human cases J. Vet. Diagn. Invest. 14:314-321.

Jubb, K.; Kennedy, P. and palmer, N. (1985): Pathology of domestic animals, $3^{\text {rd }}$ edition, Acc. Press. Inc. LTD London.

Kumar, H.; Singh, B. D.; Bal. M. S.; Kamal, P.; Randhir S.; Sidhu, P. K. and Sandhu, K. S. (2007): Pathological and epidemiological investigations into listerial encephalitis in sheep. Small Rum. Res., 71: 293 - 297.

Low, J. C. and Donachie, W. (1991): Clinical and serum antibody responses of lambs to infection by Listeria monocytogenes. Res. Vet. Sci., 51:189-192.

Low, L. C.; Wright, F.; Mc Lauchlin, J. and Donachie, W. (1993): Serotyping and distribution of Listeria isolates from cases of ovine listeriosis. Vet.. Rec., 133:165-166.
Malik, S. V.; Barbuddhe, S. B. and Chaudhari, S. P., (2002): Listeric infections in humans and animals in the Indian subcontinent: a review. Trop. Anim. Hlth. Prod.., 34:359-381.

Miettinin, A.; Husu, J. and Tuomi, J. (1990): Serum antibody response to Listeria monocytogenes, Listerial excretion, and clinical characteristics in experimentally infected goats. J. Clin. Microbiol., 28: 340-343.

Morin, D. E. (2004): Brain steam and cranial nerve abnormalities: Listeriosis, Otitis media, interno and pituitary abscess syndrome. Vet. Clin. Food Animal, 20: 243 -273.

Radostits, O. M.; Gay, C. C.; Hinchliff, K. W. and Constable, P. D. (2007): Veterinary Medicine. A textbook of the diseases of cattle, horses, sheep, pigs and goats $10^{\text {th }}$ (Ed). Saunders El Sevier printed in Spain.pp. 805- 810.

Scott, P. R. (1992): Analysis of cerebrospinal fluid from field cases of some common ovine neurological diseases. Br. Vet. J. 148:15-22.

Scott, P. R. (1993): A field study of ovine listerial meningo-encephalitis with particular reference to cerebrospinal fluid analysis as an aid to diagnosis and prognosis. Br. Vet. J., 149:165-170.

Scott, P. R. (1995): The collection and analysis of cerebrospinal fluid as an aid to diagnosis in ruminant neurological diseases: a review. Br. Vet.. J., 1151:603-614.

Scott P.R. (2004): Diagnostic techniques and clinicopathologic findings in ruminant neurological disease. Vet. Clin. Food Animal. Prac., 20:215-230.

Seaman, J. T.; Corrigan, M. J.; Cockram, F. A. and Carter, G. I. (1990): An outbreak of listerial myelitis in sheep. Aust Vet. J. 67(4): 142-143.

Snedecor, G. W. and Cochran, W. C. (1973): Statistical methods. $6^{\text {th }}$ Ed. Iowa State University Press Iowa, USA.

Soumaya S.A.S. and H.A. Amer (2002): An attempt to control the major manifestations (abortion \& nervous symptoms) attributed to Listeria monocytogenes infections in sheep. Vet. Med. J. Giza, 50(4): 639-656.

Wagner, M.; Podstatzky-Lichtenstein, L.; Lehner, A.; Asperger, H.; Wagner, M.; Podstatzky-Lichtenstein, L.; Lehner, A.; Asperger, H.; Baumgartner, W., and Brandl, E. (2000): Prolonged excretion of Listeria monocytogenes in a subclinical case of mastitis. Milchwissenschaft, 55: 3-6.

Weber, A.; Potel, J.; and Scha"fer-Schmidt, R. et al., (1995): Investigations on the occurrence of Listeria monocytogenes in fecal samples of domestic and companion animals. Zentralbl Hyg Umweltmed, 198:117123.

Wilesmith, J. W. and Gitter, M. (1986): Epidemiology of ovine listeriosis in Great Britain Vet. Rec. 119, 467-470.

Woolford, M. K. (1990): The detrimental effects of air on silage (review). J. Appl. Bacteriol., 68:101-116.

Young, D. S. (2001): Effects of disease on Clinical Laboratory test. $4^{\text {th }}$ ed.AACC.press

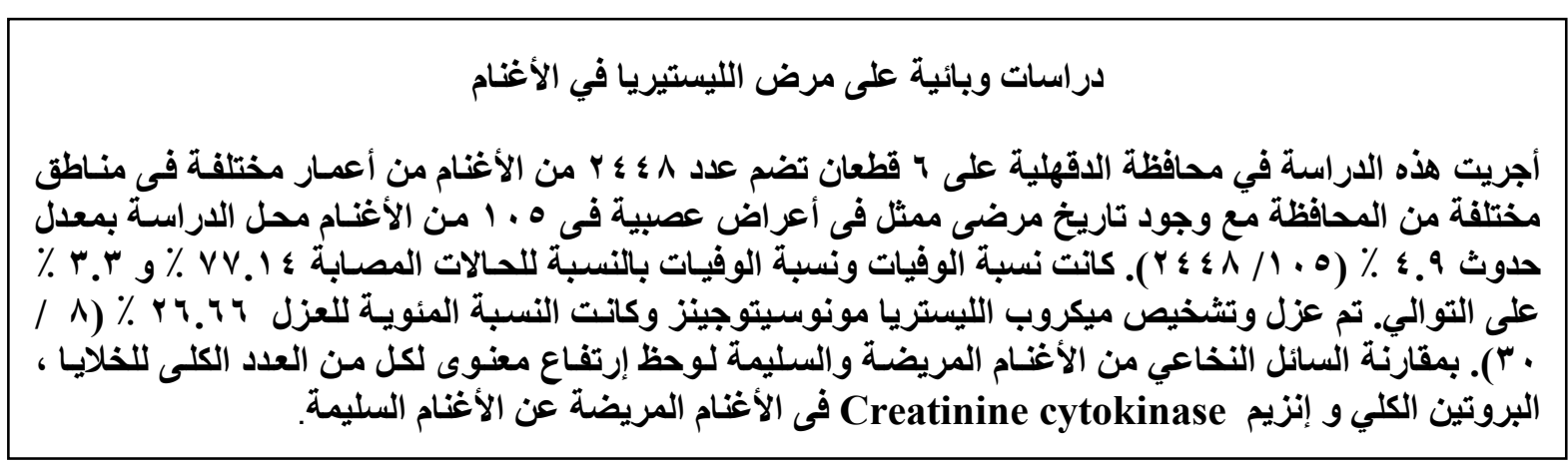

